Електронне наукове фахове видання "Ефективна економіка" включено до переліку наукових фахових видань України з питань економіки

(Категорія «Б», Наказ Міністерства освіти і науки України від 11.07.2019 № 975) www.economy.nayka.com.ua | № 7, 2021 | 29.07.2021 p.

DOI: $\underline{10.32702 / 2307-2105-2021.7 .71}$

УДК 338.124 .4

V. Antonenko

PhD in Economics, Associate Professor, Associate Professor of the Department of Management and Public Administration, Donetsk National Technical University, c. Pokrovsk

ORCID ID: 0000-0002-8220-5813

M. Amelnytska

Candidate for a degree of the Department of Management and Financial and Economic Security,

Donetsk National Technical University, Pokrovsk

ORCID ID: 0000-0001-8501-3107

\title{
METHODS OF DIAGNOSIS AND FORECASTING OF CRISIS AND BANKRUPTCY OF THE ENTERPRISE
}

\author{
В. М. Антоненко, \\ к. е. н., дочент, доцент кафедри менеджменту та державного управління, \\ Донецький національний технічний університет, м. Покровськ \\ М. І. Амельницька, \\ здобувач, кафедра управління та фінансово-економічної безпеки, \\ Донецький національний технічний університет, м. Покровськ

\section{МЕТОДИ ДІАГНОСТИКИ ТА ПРОГНОЗУВАННЯ КРИЗОВОГО СТАНУ І БАНКРУТСТВА ПІДПРИЕМСТВА}

The article examines the application of methods for diagnosing and predicting the crisis and bankruptcy of the enterprise. An analysis of theoretical approaches to the definition of "crisis diagnosis of the enterprise", which showed that today among experts there is no consensus on understanding the essence of the definition. The analysis of methodological approaches to assessing the degree of insolvency of the enterprise revealed three possible states of insolvency: current, critical and supercritical. The analysis showed that if the company is located at the beginning and end of the reporting period has signs of insolvency, it can be legally considered a debtor. In order to predict the possibility of current insolvency, it is proposed to use a rapid analysis of the financial condition of the enterprise, which should be carried out using the Beaver coefficient.

Systematization of methods used to predict the crisis and the threat of bankruptcy has allowed to group existing methods and approaches on certain grounds into groups, namely: the status of the methodological approach, information support, functional direction (research direction), the method of forming indicators. , by the method of research of estimation indicators, by the method of formation of the generalizing conclusion, by the technology of information processing.

On the basis of the analysis the comparative characteristic of the most widespread models of definition of probability of bankruptcy of the enterprise for each of which their advantages and lacks are defined is offered. The most common mathematical models for predicting the bankruptcy of the enterprise are analyzed and the criteria for their application are given. 
The considered models, the revealed shortcomings and advantages and the revealed possibilities of their use allow to draw a conclusion that in Ukraine without modification and adaptation their effective use is practically impossible.

The implementation of the outlined measures makes it possible to develop a model for diagnosing the crisis of enterprises in the market environment of Ukraine, which will be the next stage of the study.

У статті розглядається застосування методів діагностики та прогнозування кризи та банкрутства підприємства. Проведено аналіз теоретичних підходів до визначення поняття "кризова діагностика підприємства". Аналіз методологічних підходів до оцінки ступеня неплатоспроможності підприємства виявив три можливі стани неплатоспроможності: поточний, критичний та надкритичний.

Систематизачія методів, щзо використовуються для прогнозування кризи та загрози банкрутства, дозволила згрупувати існуючі методи та підходи за певними ознаками в групи.

На основі аналізу пропонується порівняльна характеристика найбільш розповсюджених моделей визначення ймовірності банкрутства підприємства, для кожної з яких визначено їх переваги та недоліки.

Розглянуті моделі, виявлені недоліки та переваги та виявлені можливості їх використання дозволяють зробити висновок, щуо в Украӥні без модифікаиії та адаптації їх ефективне використання практично неможливе.

Реалізація окреслених заходів дає змогу розробити модель діагностики кризи підприємств у ринковому середовищі України, яка стане наступним етапом дослідження.

Keywords: crisis; bankruptcy diagnosis; bankruptcy models; crisis diagnosis of the enterprise; methods of crisis assessment.

Ключові слова: криза; діагностика банкрутства; моделі банкрутства; діагностика кризового стану підприємства; методи оиінки кризового стану.

Formulation of the problem. The negative consequences of the global financial and economic crisis have exacerbated the problem of bankruptcy, which has become one of the most pressing for Ukraine and other countries. The long process of adaptation to market conditions, the instability of the economy and legislation, the lack of investment resources lead to the fact that a significant number of enterprises find themselves in a state of crisis, which in most cases ends in bankruptcy.

Domestic methodology for assessing the crisis does not meet modern requirements for business management, and foreign experience is not fully adapted to Ukrainian laws and the basic provisions of accounting and auditing. This necessitates the development of a domestic model of analysis of the company's propensity to bankruptcy, which would take into account industry specifics, stages of crisis, current performance, give an accurate and objective assessment of the crisis, based on the calculation of key indicators and indicators. The relevance of the chosen research topic is that in order to achieve effective management of the crisis and the state of bankruptcy of the enterprise it is necessary to substantiate the methods of its forecasting.

Analysis of recent research and publications. A wide range of issues related to the diagnosis of the crisis of the enterprise has been studied by both domestic and foreign economists. In particular, the works of A. Altman, L. Ligonenko, R. Lisa, O. Tereshchenko, Y. Terletskaya, J. Fomin, L. Shablista, Z. Shershneva and other scientists consider the essence, various methods and organization of the diagnostic process. However, despite the large number of works and recommendations on the nature, goals and methods of crisis diagnosis, many issues remain unclear and require further research, adaptation to domestic conditions of development.

Setting objectives. The purpose of the article is to analyze the theoretical and methodological foundations of methods for diagnosing and forecasting the crisis and bankruptcy of enterprises.

Presentation of the main research material. Bankruptcy or insolvency are categories of market economy that characterize the financial condition of economic entities. According to the Law of Ukraine "On Restoration of Debtor's Solvency or Recognition of Debtor's Bankruptcy", bankruptcy means the inability of an economic entity recognized by an arbitration court to fulfill its monetary obligations to creditors and mandatory payments within three months after the due date, as well as to restore its solvency only through the application of the liquidation procedure.

Analysis of the literature and existing views on the concept of "diagnosis of the crisis of the enterprise" shows that today there is no unambiguous approach to understanding its essence. When considering the diagnosis of the crisis of 
the enterprise, the authors put different content and essence depending on the goals, subjects, objects and methods of analysis.

The views of some domestic and foreign authors on the concept of "diagnosis of the crisis of the enterprise" are analyzed in table. 1 .

Table 1.

Analysis of approaches to the definition of "crisis diagnosis of the enterprise"

\begin{tabular}{|c|c|}
\hline Author & Definition of the concept \\
\hline L. Ligonenko [1] & $\begin{array}{l}\text { Diagnosis of problems that have arisen during the operation of the enterprise and may cause } \\
\text { negative consequences for him vital activity }\end{array}$ \\
\hline I. Blank [2] & $\begin{array}{l}\text { Targeted financial analysis system aimed at identification of the crisis state of the enterprise } \\
\text { that causes the threat of its bankruptcy }\end{array}$ \\
\hline Yu. Terletska [3] & $\begin{array}{l}\text { Determining the presence or absence of a crisis situation,on the one hand, and problem } \\
\text { identification and suggestion possible solutions - on the other }\end{array}$ \\
\hline A. Azrilian [4] & $\begin{array}{l}\text { Research focused on goal setting operation of the enterprise, methods of their achievement } \\
\text { and detection of shortcomings }\end{array}$ \\
\hline O. Ponomarenko [5] & $\begin{array}{l}\text { A necessary stage in the study of problems occurring in the process of life of a particular } \\
\text { system, which occurs after the detection of the problem as a result of control }\end{array}$ \\
\hline
\end{tabular}

Source: generated by the authors based on [1-5]

The analysis allows us to identify the following areas of crisis diagnosis:

- identification of problems regarding the negative consequences of the enterprise [1];

- conducting targeted financial analysis [2];

- establishing the presence or absence of a crisis situation [4];

- research of the purposes of functioning of the enterprise and methods of their realization [5].

Diagnosis of the crisis state of the enterprise is a set of economically sound methods and techniques of financial and economic analysis, which when applied systematically at certain intervals (depending on size, characteristics, type of activity, etc.) will identify the crisis of the enterprise and assess potential opportunities for operation and development .

Experts distinguish three degrees of insolvency: current, critical, supercritical insolvency. In order to determine which signs of insolvency characterize the financial condition of the enterprise, using the financial statements calculate the following indicators (Table 2).

Table 2.

Assessment of the degree of insolvency of the enterprise

\begin{tabular}{|c|c|c|c|c|c|}
\hline \multicolumn{3}{|c|}{ Indicator } & \multicolumn{3}{|c|}{ Degree of insolvency } \\
\hline Name & Calculation formula 1 & $\begin{array}{c}\text { Normative } \\
\text { value }\end{array}$ & Current & Critical & $\begin{array}{l}\text { Super- } \\
\text { critical }\end{array}$ \\
\hline $\begin{array}{l}\text { Current } \\
\text { solvency }\end{array}$ & $\begin{array}{c}\text { Csol }=\text { line } 040 \mathrm{f} .1+\text { line } 045 \mathrm{f} .1+ \\
\text { line } 220 \mathrm{f} .1+\text { line } 230 \mathrm{f} .1+\text { line } 240 \\
\mathrm{f} .1-\text { line } 620 \mathrm{f} .1\end{array}$ & $>1$ & Csol $<0$ & Csol $<0$ & Csol $<0$ \\
\hline $\begin{array}{c}\text { Coefficient of } \\
\text { security }\end{array}$ & $\begin{array}{c}C s=(1 L-1 A) / 2 A= \\
\text { (line.380 f.1 - line.080 f.1)/ / } \\
\text { line260 f.1 }\end{array}$ & 0,1 & $C s>0,1$ & $C s<0,1$ & $C s<0,1$ \\
\hline Coverage ratio & $\begin{array}{c}C r=2 A / 4 L= \\
\text { Line } 260 \mathrm{f} .1 / \text { line } 620 \mathrm{f} .1\end{array}$ & 1,5 & $\mathrm{Cr}>1,5$ & $C r<1,5$ & $C r<1$ \\
\hline Net profit & line $220 \mathrm{f} .2$ & $>0$ & $>0$ & $>0$ & $<0$ \\
\hline
\end{tabular}

The financial condition of the company, which at the beginning and end of the reporting quarter shows signs of current insolvency, corresponds to the legal definition of the debtor who can not fulfill its monetary obligations to creditors, including the payment of taxes and fees. Signs of critical insolvency correspond to a state of potential bankruptcy.

The presence of signs of supercritical insolvency corresponds to the financial condition of the debtor, when, according to the Bankruptcy Law, he must apply to the arbitral tribunal within a month with a statement to initiate bankruptcy proceedings.

To determine the formation of a negative balance sheet structure in a profitable enterprise, which is able in the long run to lead to signs of insolvency, it is necessary to conduct a rapid analysis of the financial condition of the enterprise. This analysis should be performed using the Beaver coefficient:

$$
C_{6}=(N P-D) /(R l t-R c) \text {; }
$$

where NP - net profit;

$D$ - depreciation;

$R l t$ - long-term responsibilities;

$R c$ - current responsibilities. 
If the value of this indicator for a long time (1.5 - 2 years) does not exceed 0.2 , it indicates the formation of an unsatisfactory balance sheet structure. The value of the Beaver coefficient recommended by international standards is in the range of $0.17-0.4$.

The current state of development of methodological support for diagnosis and forecasting of the crisis and the threat of bankruptcy is characterized by a variety of approaches and tools for its implementation. The methods used should be systematized according to the following classification features:

- status of methodical approach - state (obligatory) and scientific (recommended) methods;

- information support - quantitative, qualitative and mixed indicators;

- functional direction (research direction) - financial and property status, results of financial and economic activities, management organization, resource provision, combined approach;

- methods of forming evaluation indicators - coefficient, aggregate and index approaches;

- methods of research of evaluation indicators - dynamic (retrospective), comparative, reference analysis;

- methods of forming a generalized conclusion - subjective and objective methods - index, point, graphical, statistical methods;

- information processing technology - automated, non-automated.

Any method of assessing creditworthiness is, in essence, a method of predicting bankruptcy. Based on [6-8] in table. Figure 3 shows a comparative description of the most common models for determining the probability of bankruptcy.

The vast majority of experts suggest to evaluate the financial performance of joint stock companies to use a systematic method of analysis of financial statements and DuPont corporations. The method is based on the hypothesis that the success of joint-stock creativity depends on the decisions made by its governing bodies in three areas: production activities; investment activity; financial activities [9].

Table 3.

Advantages and disadvantages of models for determining the probability of bankruptcy

\begin{tabular}{|c|c|c|}
\hline Model & Benefits & Недоліки \\
\hline Fox model & Simplification of calculations & $\begin{array}{l}\text { Not adapted to Ukrainian enterprises, was created taking into } \\
\text { account western features of development }\end{array}$ \\
\hline $\begin{array}{l}\text { Taffler and } \\
\text { Tisshaw model }\end{array}$ & Simplification of calculations & $\begin{array}{l}\text { Used only for companies that quote their shares on stock } \\
\text { exchanges }\end{array}$ \\
\hline $\begin{array}{l}\text { Universal } \\
\text { discriminatory } \\
\text { function }\end{array}$ & $\begin{array}{c}\text { Wide criteria rating scale, } \\
\text { systemic and integrated } \\
\text { approaches }\end{array}$ & $\begin{array}{l}\text { High degree of complexity decision making in the conditions } \\
\text { multicriteria task. Informative character calculated indicators. } \\
\text { Model used only enterprises of the USA and Europe }\end{array}$ \\
\hline Springgate model & Accuracy about $90 \%$ & $\begin{array}{c}\text { Created for US and Canadian valuation companies } \\
\text { creditworthiness of enterprises }\end{array}$ \\
\hline $\begin{array}{l}\text { Five-factor } \\
\text { Altman's model }\end{array}$ & $\begin{array}{l}\text { Simplification of calculations } \\
\text { and the presence of a sequence } \\
\text { of analysis }\end{array}$ & $\begin{array}{c}\text { Used only on large enterprises (JSC) of the USA. For } \\
\text { domestic enterprises complicated by differences accounting, } \\
\text { underdeveloped stock market }\end{array}$ \\
\hline Flumer's model & $\begin{array}{c}\text { Wide coverage } \\
\text { indicators, probability - } 1 \text { year } \\
-98 \%, 2 \text { years }-81 \%\end{array}$ & $\begin{array}{l}\text { Used only in banking practice and was created with taking } \\
\text { into account the specifics of the West countries, so a } \\
\text { correction is needed national currency }\end{array}$ \\
\hline
\end{tabular}

The DuPont method is based on the analysis of ratios, which creates a return on equity (Return of Equity or ROE):

$$
R O E=N I / C E,
$$

where NI (Net Incjme) - net profit;

$C E$ (Common Equity) - share capital.

There are several versions of the method that differ in the degree of detail.

1. Two-member version.

$$
R O E=N I / C E=N I \bullet T A / T A \cdot C E,
$$

where TA (Total Assets) - total assets of joint stock.

Otherwise you can write:

$$
R O E=R O A \cdot L R,
$$

where ROA (Return of Assets) - return on assets;

$L R$ (Leverage Ratio) - the ratio of financial leverage.

2. Three-member version: 


$$
R O E=N I / C E=N I \bullet T A \bullet N S / T A \bullet C E \bullet N S,
$$

where - NS (Net Sales) - net (excluding VAT, sales taxes and sales taxes) sales volume.

Otherwise:

$$
R O E=N P M \bullet A T \cdot L R,
$$

where NPM (Net Profit Margin) - profitability;

$A T$ (Asset Turnover) - asset turnover.

3. Five-member version.

$$
R O E=N I / C E=N I \bullet T A \bullet N S \bullet E B T \bullet E B I T / T A \bullet C E \bullet E B T \bullet E B I T \bullet N S,
$$

where EBT (Earning befour Taxes) - profit before taxes;

EBIT (Earning without Interest and Taxes) - earnings before interest and taxes.

Otherwise you can write:

$$
R O E=T B \cdot I B \cdot O M \bullet A T \cdot L R
$$

where $T B$ (Tax Burden) - tax burden;

$I B$ (Interest Burden) - interest burden;

$O M$ (Operating Margin) - operating profitability.

When analyzing the financial condition of joint stock companies, considerable attention should be paid to the method of predicting bankruptcy. Bankruptcy prediction techniques began to be used to predict risks in crisis management, and then to diagnose strategic problems. Each technique has its positive and negative features that need to be considered when choosing them to solve diagnostic problems.

The founder of bankruptcy forecasting is Edward Altman, who gained worldwide recognition after creating a mathematical formula that measures the degree of risk of bankruptcy of each individual company ( $Z$ scoremodel). Based on a survey of bankrupt enterprises, Altman determined the coefficients of significance of individual factors in the integrated assessment of the possibility of bankruptcy. This model looks like this:

$$
Z=1,2 \cdot X 1+1,4 \cdot X 2+3,3 \cdot X 3+0,6 \cdot X 4+X 5
$$

where $Z$ is an integral indicator of the level of threat of bankruptcy;

$X 1$ - the ratio of working capital to the amount of assets;

$X 2$ - the ratio of retained earnings to the amount of liabilities (level of return on capital);

$X 3$ - the ratio of operating profit to the amount of liabilities (level of return on assets);

$X 4$ - the ratio of market value of shares to debt;

$X 5$ - the ratio of revenue to total assets.

As a result of calculation of $Z$ - indicator for the concrete enterprise the conclusion becomes:

If $Z<1,81$ - the probability of bankruptcy is from 80 to $100 \%$;

If $Z=1,81-2,77$ - the average probability of failure of the company from 35 to $50 \%$;

If $Z=2,77-2,99$ - the probability of bankruptcy is not high from 15 to $20 \%$;

If $Z>2,99$ - the situation at the enterprise is stable, the risk of insolvency in the next two years is extremely small.

Thus, the researched enterprise has a stable situation, the risk of insolvency for 2 years is extremely small.

The accuracy of the forecast in this model on the horizon of one year is $95 \%$, and two years - $83 \%$. The disadvantage of this model is that it can be considered only in relation to large companies that have placed their shares on the stock market.

Gordon LV Springgate in 1978, based on the Altman model and step-by-step discriminant analysis, developed his own model for predicting the probability of bankruptcy. Estimation of the probability of bankruptcy according to the Springgate model is carried out according to the formula:

$$
Z=1,03 \cdot X 1+3,07 \cdot X 2+0,66 \cdot X 3+0,4 \cdot X 4,
$$

where $X 1$ - working capital / total assets;

$X 2$ - (operating profit + interest payable) / total assets;

$X 3$ - operating profit / short-term liabilities;

$X 4$ - net sales revenue / total assets.

The value of the calculated indicator for each year of analysis exceeds 0.862 , therefore, the company cannot be potentially bankrupt.

At $Z<0,862$ the company is potentially bankrupt. 
In the process of testing the Springgate model on the basis of data from 40 companies, the accuracy of predicting insolvency for the year ahead was set at $92.5 \%$.

The advantages of this model are that in general the forecasting error does not exceed 10\%; also does not take into account the market capitalization of enterprises (not limited to joint stock companies). However, the Springgate model has significant drawbacks: forecasting accuracy decreases over time; the model is a modification of the $\mathrm{Z}$ (Altman account of the 1968 version) (the latter is obsolete and unsuitable for modern use).

Ukrainian companies can use the Springgate model as an additional one, as it does not take into account noneconomic factors.

Among domestic models it is necessary to pay attention to the discriminant model OO Tereshchenko. The peculiarity of this technique is that it has somewhat biased estimates. It emphasizes the reduction of erroneous assignment of financially insolvent enterprises to the group of sustainable. Such asymmetry aims to protect the investor from risky investment, but reduces the accuracy of the forecast as a whole [10].

Tereshchenko's model is determined by the formula:

$$
Z=1,5 \cdot X 1+0,08 \cdot X 2+10 \cdot X 3+5 \cdot X 4++0,3 \cdot X 5+0,1 \cdot X 6
$$

where $X 1$ is the ratio of cash receipts to liabilities;

$X 2$ - the ratio of balance sheet currency to liabilities;

$X 3$ - the ratio of net income to the average annual amount of assets;

$X 4$ - the ratio of profit to revenue;

$X 5$ - the ratio of inventories to revenue;

$X 6$ - the ratio of revenue to fixed capital.

When $Z>2$ - bankruptcy is not threatened, $1<Z<2$ - financial stability is violated, $0<Z<1$ - there is a threat of bankruptcy.

The disadvantages of this model of Tereshchenko are insufficient justification of the critical points of individual indicators, which leads to inaccuracy in fixing the standards of financial indicators, as well as the fact that it has a wide range of uncertainty.

It is worth paying attention to the model A.V. Matviychuk, which was developed for Ukrainian enterprises taking into account the specifics of the transition economy and the functioning of economic entities in such conditions, and therefore most adequately characterizes the existing financial and economic condition of the enterprise.

The method of calculating this model is given in the formula:

$$
Z=0,033 \cdot X 1+0,268 \cdot X 2+0,045 \cdot X 3-0,018 \cdot X 4-0,004 \cdot X 5-0,015 \cdot X 6+0,702 \cdot X 7
$$

where $X 1$ - asset mobility ratio;

$X 2$ - turnover ratio of accounts payable;

$X 3$ - turnover ratio of equity;

$X 4$ - return on assets;

$X 5$ - the ratio of own working capital;

X6 - concentration ratio of borrowed capital;

$X 7$ - debt capital ratio.

If when using this model to assess the financial condition, we obtain a value of $Z$, which is greater than 1,104 , it indicates a satisfactory financial condition of the enterprise and a low probability of bankruptcy. And the higher the value of $Z$, the more stable the position of the company. If the value of $Z$ for the company was less than 1,104 , then there is a threat of financial crisis. With a further decrease in $Z$, the probability of bankruptcy of the analyzed enterprise increases [11].

The disadvantage of the model is that it is created taking into account the specifics of the functioning of banks, which may not be objective enough for industrial enterprises. The allocation of only two classes of the state of the enterprise in the construction of a discriminant model is not always sufficient to assess the real financial situation.

Conclusions. The choice of methods and models for diagnosing crisis and bankruptcy of enterprises depends on the goals and subjects, objects of analysis, features of activities and potential capabilities of the enterprise to avoid or reduce the risk of crisis or, as a critical case, bankruptcy.

Analyzed models, identified shortcomings and advantages and identified opportunities for their use give reason to note that in Ukraine without modification and adaptation, their effective use is almost impossible. This requires the possibility of an objective assessment of the financial condition of enterprises of all forms of ownership and organizational and legal forms of management; availability of a database of individual business entities; clear definition of the purposes of subjects and objects of the analysis taking into account features of the enterprises and conditions of their functioning.

The implementation of the outlined measures makes it possible to develop a model for diagnosing the crisis and bankruptcy of enterprises in the market environment of Ukraine, which forms the basis for the prospects of research in this area. 


\section{References.}

1. Lihonenko, L. O. (2001), Antykryzove upravlinnia pidpryiemstvom: teoretyko-metodolohichni zasady ta praktychnyi instrumentarii: monohrafiia [Anti-crisis management of the enterprise: theoretical and methodological principles and practical tools: monograph], Nats. torh.-ekon. un-t, Kyiv, Ukraine

2. Blank, I. O. and Sytnyk, H. V. (2006), Upravlinnia finansamy pidpryiemstva: pidruchnyk [Enterprise financial management: a textbook], Kyiv. nats. torh.-ekon. un-t, Kyiv, Ukraine

3. Terletska, Yu. O. (2006), "Anti-crisis diagnostics of the enterprise: methods, methods and conditions of application”, Visnyk Donetskoho universytetu. Seriia V: Ekonomika i pravo, vol. 1, pp. 504-509

4. Azrylyian, A. N. (2002), Bolshoi ekonomycheskyi slovar [Big Dictionary of Economics], 5rd ed., Ynstytut novoi ekonomyky, Moscow, Russia

5. Ponomarenko, O. (2007), Systemni metody v ekonomitsi, menedzhmenti, biznesi [System methods in economics, management, business], Osnovy, Kyiv, Ukraine

6. Prokhorova, Yu. V. (2008), "Analysis of modern methods and models for diagnosing crisis states of mechanical engineering enterprises", Byznes-Ynform, vol. 2, pp. 52-57.

7. Fuchedzhy, V. I. (2010), "Characteristics of methods and models for diagnosing the crisis of the enterprise", Menedzhment ta pidpryiemnytstvo v Ukraini: etapy stanovlennia i problemy rozvytku [Management and entrepreneurship in Ukraine: stages of formation and problems of development], Vydavnytstvo Lvivskoi politekhniky, Lviv, Ukraine, pp. $240-245$.

8. Ridderstrale, J. and Nordstrom, K. (2003), Karaoke Capitalism, Bookhouse Publishing, London, UK

9. Hammes, D. L. (1992), Review of "Conflict in Economics", Kyklos, vol. 45, no. 2, pp. 308-311

10. Balabanov, I. T. (2012), "Component assessments of financial resources management of enterprises", available at: http://www.nbuv.gov. ua/portal/soc_gum/tppe/ (Accessed 14 June 2021)

11. Berdar, M. M. (2015), "Management of the process of formation and use of financial resources of the enterprise", Aktualni problemy ekonomiky, vol. 5, pp. 133-138.

\section{Літкратура.}

1. Лігоненко, Л. О. Антикризове управління підприємством: теоретико-методологічні засади та практичний інструментарій: монографія. К.: Київ. нац. торг.-екон. ун-т, 2001. 580 с.

2. Бланк, І. О., Ситник, Г. В. Управління фінансами підприємства: підручник. К. : Київ. нац. торг.екон. ун-т, 2006. $780 \mathrm{c.}$

3. Терлецька, Ю. О. Антикризова діагностика підприємства: методи, способи та умови застосування. Вісник Донецького університету. Серія В: Економіка і право. 2006. Т. 2, № 1. С. 504-509.

4. Большой экономический словарь / под ред. А. Н. Азрилияна. 5-е изд. доп. и перераб. М. : Институт новой экономики, 2002. 1280 с.

5. Пономаренко, О. Системні методи в економіці, менеджменті, бізнесі. К.: Основи, 2007. 390 с

6. Прохорова, Ю. В. Анализ современных методов и моделей диагностики кризисних состояний предприятий машиностроения. Бизнес-Информ. 2008. № 2. С. 52-57.

7. Фучеджи, В. І. Характеристика методів та моделей діагностики кризового стану підприємства. Менеджмент та підприємництво в Україні: етапи становлення і проблеми розвитку: [збірник наукових праць]/ відп. ред. О. С. Кузьмін. Львів: Видавництво Львівської політехніки, 2010. С. 240-245.

8. Ridderstrale, J., Nordstrom, K. Karaoke Capitalism. N., 2003. 629 p.

9. Hammes, D, L. Review of "Conflict in Economics" (Varoufakis Y., Young D.). Kyklos. 1992. V. 45. Issue 2. P. 308-311

10. Балабанов, I. Т. Складові оцінки управління фінансовими ресурсами підприємств, 2012. [Електронний ресурс]. - Режим доступу: http://www.nbuv.gov. ua/portal/soc_gum/tppe/

11. Бердар, М. М. Управління процесом формування і використання фінансових ресурсів підприємства. Актуальні проблеми економіки. 2015. № 5. С. 133-138. 